\title{
ON THE CULTIVATION OF CAULERPA RACEMOSA VAR. OCCIDENTALIS IN THE PHILIPPINES AND SOME ASPECTS OF THE PHYSIOLOGICAL ECOLOGY
}

\author{
by
}

\author{
A. COLINA ${ }^{1)}$, U. Horstman ${ }^{1)}$, and W. SChramm ${ }^{1)}$
}

\begin{abstract}
Caulerpa racemosa, a benthic siphonaceous algae has its natural habitat in the sublittoral zone of tropical areas. In the Philippines, since a few years, it is cultivated on commercial scale in flooded ponds in the intertidal mangrove zone. Unlike in their natural habitats, Caulerpa in these ponds is subjected to sometimes considerable changes in salinity (rain, evaporation, temperature and light (insolation), and in $\mathrm{pH}$ ). The response of Caulerpa to these factors and the comparison of the ecological conditions, both in the natural habitats and the cultured ponds have been investigated.

The experiments showed that the observed changes of the studied parameters normally range within the physiological limits of Caulerpa. Under extreme conditions, however, detrimental effects can occur. Ways of controlling such factors are discussed.
\end{abstract}

1). Marine Research Office, University of San Carlos, Cebu City 6401, Philippines 